\title{
THE
}

\section{PLASMA TYROSINE LEVELS OF PREMATURE BABIES}

BY

\author{
JOHN MATHEWS and MICHAEL W. PARTINGTON \\ From the Department of Paediatrics, Queen's University, and \\ Kingston General Hospital, Kingston, Ontario, Canada
}

(RECEIVED FOR PUBLICATION DECEMBER 3, 1963)

There is good evidence that under certain conditions the newborn baby metabolizes tyrosine in a different way from the older child or adult. Levine and his colleagues (Levine, Gordon, and Marples, 1941a; Levine, Marples, and Gordon, 1941 b; Levine, 1947) first described the excretion of large amounts of tyrosine, p-hydroxyphenylpyruvic acid, and p-hydroxyphenyllactic acid in the urine of premature babies given high protein diets. This has also been observed in certain full-term babies on normal diets (Bloxam, Day, Gibbs, and Woolf, 1960) or after loading with either phenylalanine or tyrosine (Levine, 1947). The condition was originally called hydroxyphenyluria (Levine, 1947) but is now more usually referred to as tyrosyluria (Kretchmer and Etzwiler, 1958). Levine believed that the disorder was specifically related to vitamin $C$ since the administration of this vitamin would prevent or eradicate the tyrosyluria (Levine et al., 1941a). Furthermore, tyrosyluria is also found in scorbutic guinea-pigs (Sealock and Silberstein, 1940) and human scurvy (Morris, Harpur, and Goldbloom 1950). Other substances, for example, folic acid (Nitowsky, Govan, and Gordon, 1953) or corticotrophin (Etzwiler, McNamara, Kretchmer, and Levine, 1957), will also eliminate the tyrosyluria of premature babies but these are less certain and effective than ascorbic acid (Levine, 1956).

Kretchmer (1958) concluded from in vitro observations on foetal and neonatal liver that tyrosyluria was due to a delay in maturation of the enzymes tyrosinase and p-hydroxyphenylpyruvic oxidase after birth. Etzwiler et al. (1957) showed that this form of tyrosyluria was accompanied by raised blood levels of tyrosine. More recently Hsia, Litwack, O'Flynn, and Jakovcic (1962) and $\mathrm{La} \mathrm{Du,}$ Howell, Michael, and Sober (1963) have reported raised levels of tyrosine in the serum of premature babies. La Du et al. (1963) found that 7 out of 30 premature babies had serum tyrosine levels above $16 \mathrm{mg} . / 100 \mathrm{ml}$. in the first and second weeks of life. These workers were unable to correlate the blood tyrosine level with the birth weight, and some, but not all, of the babies who developed raised tyrosine levels had been given supplemental dietary ascorbic acid.

We have studied 40 premature babies and have found that $12\left(30^{\circ}\right)$ developed marked but transient increases in the plasma tyrosine level (above $20 \mathrm{mg}$./ $100 \mathrm{ml}$.) in the newborn period. The clinical significance of these findings is not clear. However, if instead of tyrosine, the closely related amino acid phenylalanine were involved, one might well expect a raised blood level of this magnitude to be harmful at this age (Berman, Graham, Eichman and Waisman, 1961 ; Partington and Lewis, 1963). It has already been suggested that, in one patient, prolonged tyrosyluria led to developmental retardation (Menkes and Jervis, 1961).

This paper records some observations on the plasma tyrosine level of premature babies in relation to a number of factors including birth weight, age, protein and ascorbic acid intake, and the tissue ascorbic acid content.

\section{Materials and Methods}

The series consisted of $\mathbf{4 0}$ babies admitted to the Premature Nursery of the Kingston General Hospital. There were 16 boys and 24 girls. All the babies were premature by weight (less than $2,500 \mathrm{~g}$. at birth) though not necessarily by the estimated gestation period (Table 1 ).

The babies were fed different formulae according to the prescription of the attending physician; the majority were given 'Olac' (Mead Johnson Ltd.) in various dilutions. The amount of formula taken at each feed was carefully recorded by the nurses. The protein intake was estimated on the basis of the manufacturer's statement of the protein content of the individual formula and was expressed as g. protein/kg. body weight/day. Ascorbic 
TABLE 1

BIRTH WEIGHTS AND ESTIMATED GESTATION PERIODS OF THE BABIES

\begin{tabular}{|c|c|c|c|c|c|c|c|c|c|}
\hline \multirow{2}{*}{$\begin{array}{c}\text { Birth } \\
\text { Weight } \\
\text { (g.) }\end{array}$} & & \multicolumn{8}{|c|}{ Gestation Period (weeks) } \\
\hline & & $27-29$ & $30-31$ & $32-33$ & $34-35$ & $36-37$ & $38-39$ & $40-42$ & Unknown \\
\hline $\begin{array}{r}900-1,099 \\
1,100-1,299 \\
1,300-1,499 \\
1,500-1,699 \\
1,700-1,899 \\
1,900-2,099 \\
2,100-2,299 \\
2,300-2,499\end{array}$ & $\begin{array}{l}\cdots \\
\cdots \\
\cdots \\
\cdots \\
\cdots \\
\cdots \\
\cdots\end{array}$ & 1 & 1 & $\begin{array}{l}1 \\
3 \\
3\end{array}$ & $\begin{array}{l}1 \\
3 \\
3 \\
1\end{array}$ & $\begin{array}{l}1 \\
1\end{array}$ & $\frac{2}{4}$ & $\begin{array}{l}1 \\
1 \\
3 \\
1\end{array}$ & $\begin{array}{l}1 \\
1 \\
1 \\
2\end{array}$ \\
\hline
\end{tabular}

acid was given by mouth in the form of 'PolyVisol' or 'TriVisol' (Mead Johnson Ltd.) and was usually introduced into the diet on the fourteenth day of life. In a few cases the baby was given breast milk or else an ascorbic acid fortified formula (ascorbic acid content $52 \mathrm{mg} . / 1,000$ ml.).

Millon's test was performed by adding a few drops of Millon's reagent to about $3 \mathrm{ml}$. of urine. A white precipitate, which turned dark red after boiling, was taken as a positive test. The result was graded as,,,- \pm- - , and $-\ldots-$ according to the intensity of the colour that developed.

Blood was obtained by femoral puncture and collected into oxalated bottles. The cells and plasma were separated and the plasma was stored frozen for the subsequent estimation of tyrosine by the method of Udenfriend and Cooper (1952). In certain patients $3 \mathrm{ml}$. of fresh blood was put into a saline-dextran-EDTA diluent for estimation of the ascorbic acid content of the white blood cells by the method of Denson and Bowers (1961). The method was slightly modified by the use of a celloscope (Ljungberg and Co.) for enumerating the white blood cells instead of chamber counting. The values were expressed as micrograms of ascorbic acid per $10^{6}$ white blood cells ( $\mu \mathrm{g}$. ascorbic acid $/ 10^{8} \mathrm{wbc}$ ). With this method the mean difference between paired estimates from 13 subjects was $1.9 \mu \mathrm{g} .10^{\circ}$ wbc with a standard deviation (S.D.) of $1 \cdot 2$.

\section{Results}

Millon's Test on the Urine. Millon's test on the urine indicates the presence of tyrosine, p-hydroxyphenylpyruvic, p-hydroxyphenyllactic and phydroxyphenylacetic acids (Kitagawa and Yoshioka, 1960). The test was used extensively by Levine $e t$ al. (1941b) in their observations on tyrosyluria. It seemed of interest to compare the reaction of the urine to Millon's test with the plasma tyrosine level.

Samples of blood and urine were collected from each baby within two hours of one another. The relation between the plasma tyrosine level and Millon's test on the urine in $\mathbf{1 0 5}$ paired samples from 40 babies is shown in Fig. 1. It can be seen that negative $(-)$ and trace $( \pm)$ reactions with Millon's test were associated with plasma tyrosine levels below $10 \mathrm{mg}$. $/ 100 \mathrm{ml}$. in all but 3 instances. With plasma tyrosine levels above $10 \mathrm{mg} . / 100 \mathrm{ml}$. the Millon's reaction was nearly always positive. However, positive Millon's reactions were also found when the plasma tyrosine was less than $10 \mathrm{mg} . / 100 \mathrm{ml}$.

It was concluded that a negative or trace Millon's test on the urine nearly always indicated a plasma tyrosine level less than $10 \mathrm{mg}$. $/ 100 \mathrm{ml}$. but that no reliable information about the plasma tyrosine level could be inferred from a positive Millon's test.

Age. In Fig. 2, 118 estimations of the plasma tyrosine level in the $\mathbf{4 0}$ babies are shown in relation to the baby's age. It was found that during the first week of life the plasma tyrosine level was usually less than $10 \mathrm{mg}$. $/ 100 \mathrm{ml}$. The average value between 0 and 6 days of age was $4.37 \mathrm{mg} . / 100 \mathrm{ml}$. $(\mathrm{n}=26$; S.D. $=2 \cdot 72$ ). In the second to the fifth weeks of life, although most of the plasma tyrosine levels were less than $10 \mathrm{mg} . / 100 \mathrm{ml}$., a number were much higher. In consequence, the mean levels were increased ( $7-13$ days, $11 \cdot 74 ; 14-20$ days, $8 \cdot 72 ; 21-27$ days $9 \cdot 71,28-34$ days, $7 \cdot 73 \mathrm{mg} . / 100 \mathrm{ml}$.). From inspection of Fig. 2, however, it can be seen that the average plasma tyrosine level has little meaning, since the distribution of the levels in the first five weeks of life appears to be bimodal; i.e. either the plasma tyrosine level was lower than $10 \mathrm{mg}$. $/ 100 \mathrm{ml}$. or else it was higher than $20 \mathrm{mg}$. $/ 100 \mathrm{ml}$.; few values were recorded between these levels. This bimodal distribution is also evident in Fig. 3, and Tables 2 and 3. It is also apparent in the serum tyrosine levels of premature babies reported by Hsia et al. (1962) and by La Du et al. (1963).

Over the age of 34 days most of the plasma tyrosine levels were less than $10 \mathrm{mg}$. $/ 100 \mathrm{ml}$.

Protein Intake. Levine (1947) found tyrosyluria in premature babies only when they were taking more than $4 \mathrm{~g}$. protein $/ \mathrm{kg}$./day. Fig. 3 shows the relation between the dietary protein intake and the plasma tyrosine levels in the present series. The protein intake was estimated as the average daily intake of the three days before the collection of the blood 
TABLE 2

RELATION BETWEEN BIRTH WEIGHT AND HIGHEST PLASMA TYROSINE LEVEL RECORDED IN 32 BABIES WHO TOOK MORE THAN 5 g. PROTEIN/kg. DAY

\begin{tabular}{|c|c|c|c|c|c|c|}
\hline \multirow{2}{*}{ Birth Weight (g.) } & \multicolumn{6}{|c|}{ Plasma Tyrosine $(\mathrm{mg} / 100 \mathrm{ml}$ ) } \\
\hline & $0-9$ & 10-19 & $20-29$ & $30-39$ & $40-49$ & $50-59$ \\
\hline $\begin{array}{r}900-1.299 \\
1.300-1.699 \\
1.700-2.099 \\
2.100-2.499\end{array}$ & $\begin{array}{r}9 \\
10\end{array}$ & & 3 & $\begin{array}{l}1 \\
4\end{array}$ & $\begin{array}{l}1 \\
1\end{array}$ & 1 \\
\hline
\end{tabular}

sample. The observations are confined to those made in the second to fourth weeks of life (7-28 days of age). Measurements made on babies who were receiving ascorbic acid in their formula or as a dietary supplement are distinguished by a separate symbol.

It can be seen (Fig. 3) that when the protein intake was less than $5 \mathrm{~g}$. $/ \mathrm{kg}$./day, the plasma tyrosine was less than $10 \mathrm{mg}$. and usually less than $5 \mathrm{mg}$. At higher protein intakes, the plasma tyrosine level was less than $10 \mathrm{mg}$. in some cases but in others it was increased to $20 \mathrm{mg}$. $/ 100 \mathrm{ml}$. or more. The tyrosine levels were again distributed into two groups. In other words, at protein intakes above $5 \mathrm{~g}$. $/ \mathrm{kg}$./day the plasma tyrosine level was either between 2 and 10 mg. or between 20 and $45 \mathrm{mg}$. $/ 100 \mathrm{ml}$; very few estimations were outside these limits.

There was no obvious relation between the presence or absence of ascorbic acid in the diet and the plasma tyrosine level; at least half of the babies who developed high plasma tyrosine levels were being given ascorbic acid.

Birth Weight and Maturity. Tables 2 and 3 show the highest plasma tyrosine levels recorded in each of the 32 babies who took more than $5 \mathrm{~g}$. protein $/ \mathbf{k g}$./ day, in relation to their birth weight (Table 2) and their estimated gestation period (Table 3). Both Tables emphasize the separation of the plasma tyrosine levels into two groups. A slightly greater proportion of the babies with low birth weights and short gestation periods developed large increases in

TABLE 3

RELATION BETWEEN ESTIMATED GESTATION PERIOD AND HIGHEST PLASMA TYROSINE LEVEL IN 32 BABIES WHO TOOK MORE THAN 5 g. PROTEIN/Kg. DAY

\begin{tabular}{|c|c|c|c|c|c|c|}
\hline \multirow{2}{*}{$\begin{array}{c}\text { Gestation Period } \\
\text { (weeks) }\end{array}$} & \multicolumn{6}{|c|}{ Plasma Tyrosine (mg. $100 \mathrm{ml}$ ) } \\
\hline & $0-9$ & $10-19$ & $20-29$ & $30-39$ & $40-49$ & $50-59$ \\
\hline $\begin{array}{ll}27-31 & \ldots \\
32-35 & \cdots \\
36-39 & \cdots \\
40 \div & \ldots \\
\text { Not known }\end{array}$ & $\begin{array}{l}2 \\
7 \\
4 \\
3 \\
4\end{array}$ & & $\begin{array}{l}1 \\
2 \\
1\end{array}$ & $\begin{array}{l}4 \\
1\end{array}$ & 1 & 1 \\
\hline
\end{tabular}

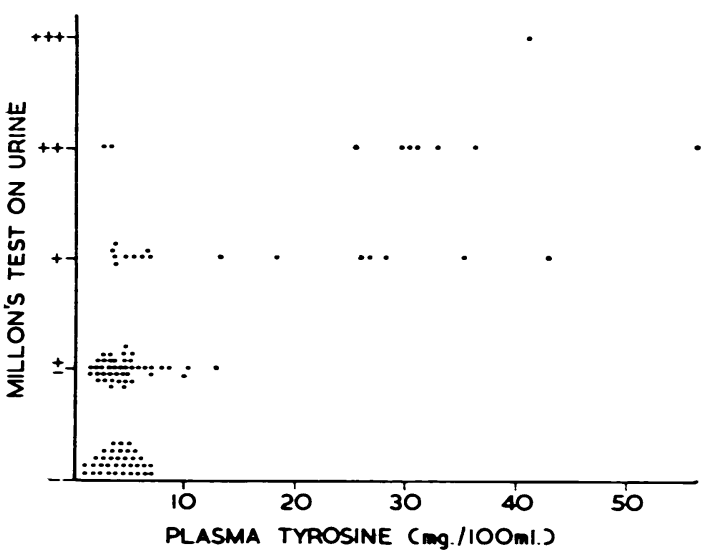

Fig. 1.-Relation between the plasma tyrosine level and Millon's test on the urine in 105 paired samples from $\mathbf{4 0}$ babies.

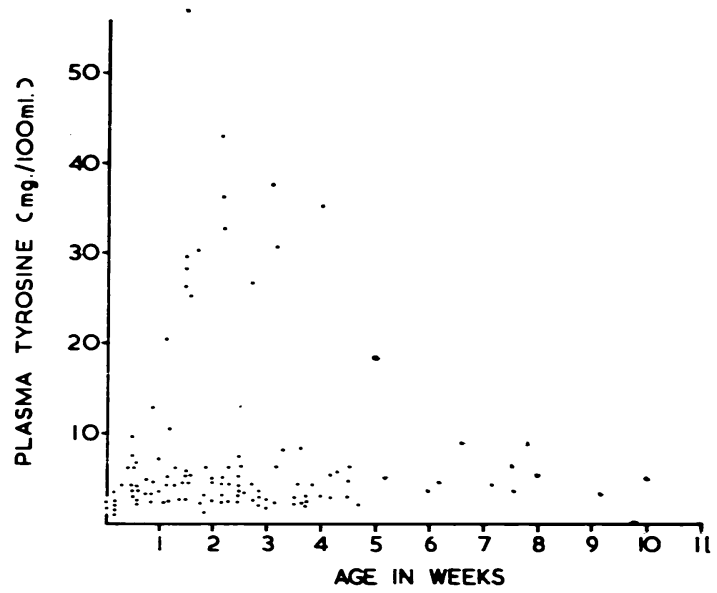

FiG. 2. The plasma tyrosine level of premature babies related to age

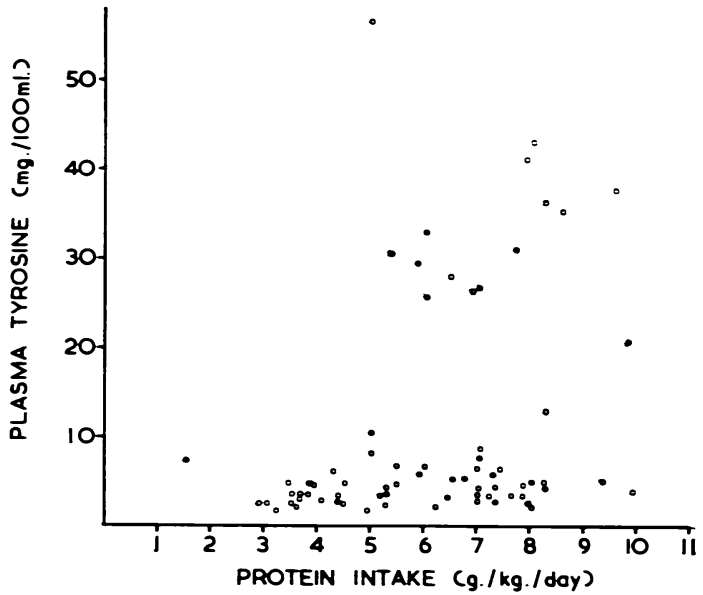

Fig. 3.-The plasma tyrosine level of premature babies related to protein intake. Solid circles = no ascorbic acid in the diet; open circles $=$ ascorbic acid in the diet. 


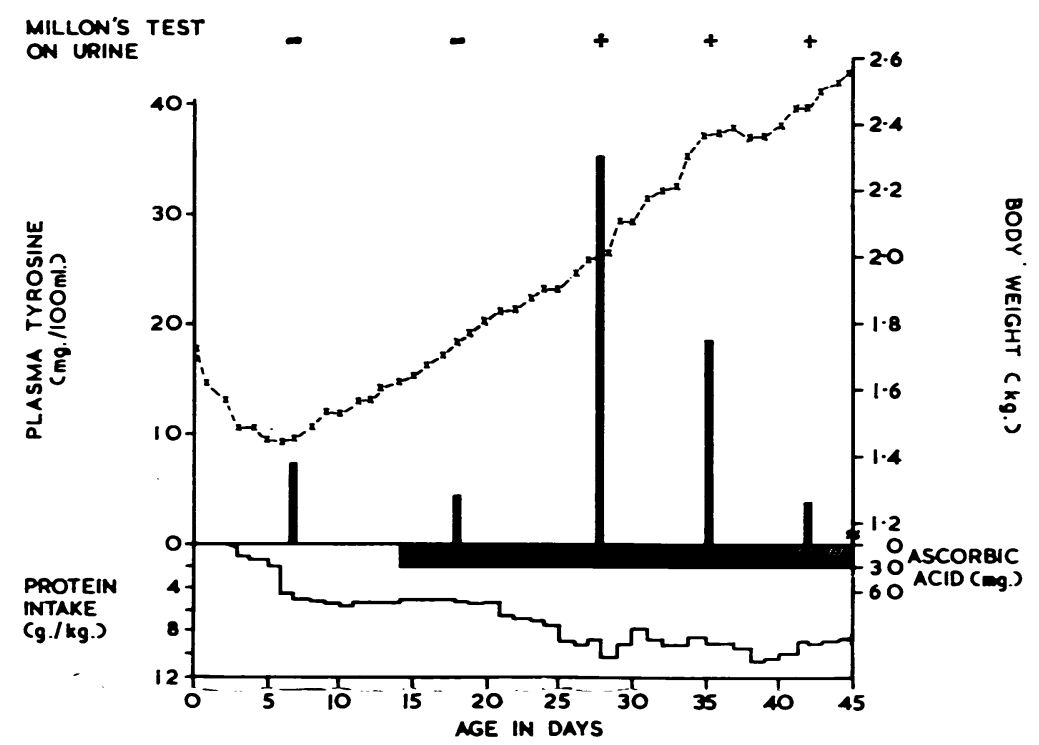

Fig. 4. - Case 11. Changes in plasma tyrosine level, protein intake, and body weight in the first 45 days of life.

their plasma tyrosine levels, but there was no direct relation between the tyrosine levels and either of these factors.

Ascorbic Acid Intake. Levine (1947) found that, in general, ascorbic acid in the diet eliminated tyrosyluria in premature babies. In our series, however, the presence or absence of dietary ascorbic acid did not appear to influence the height of the plasma tyrosine level in those babies who took more than $5.0 \mathrm{~g}$. protein $/ \mathrm{kg}$./day (Fig. 3). In some babies (e.g. Twin B, Fig. 5) the introduction of $30 \mathrm{mg}$. of ascorbic acid a day was followed by a marked fall in the plasma tyrosine level despite an increase in the protein intake. In other cases (e.g. Case 11, Fig. 4) the baby developed a high plasma tyrosine level ( 35 $\mathrm{mg} . / 100 \mathrm{ml}$.) on the $28 \mathrm{th}$ day of life despite a daily intake of $30 \mathrm{mg}$. of ascorbic acid from the age of 14 days. Another baby, after 13 days of $60 \mathrm{mg}$. per day supplemental ascorbic acid, had a plasma

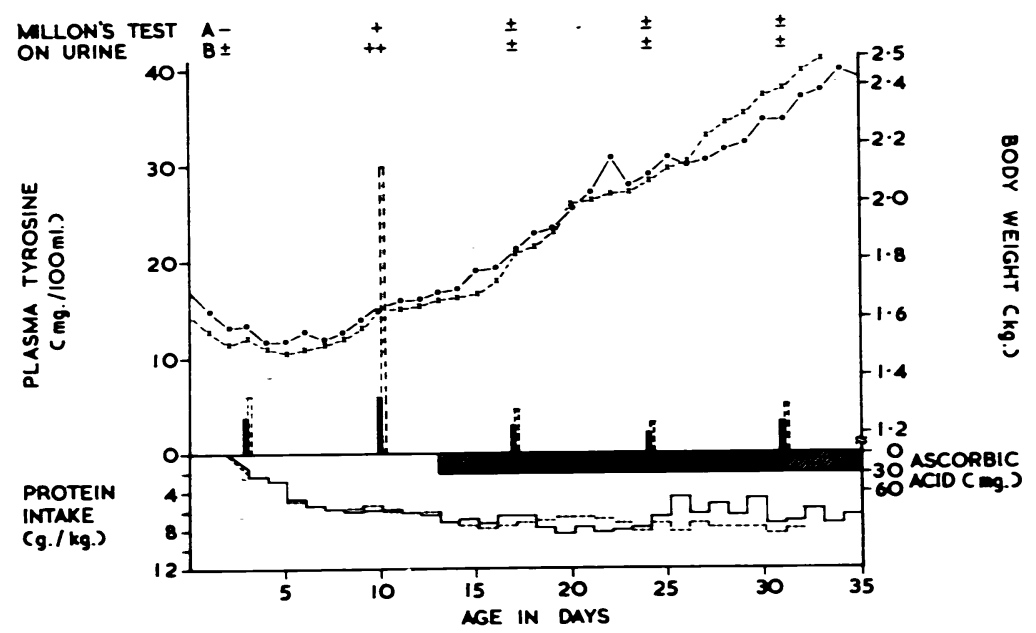

FiG. 5.-Cases 1 and 2. Changes in plasma tyrosine kevel, protein intake, and body weight in monozygotic twins. Twin A represented by the solid lines, Twin B by the broken lines. 
TABLE 4

ASCORBIC ACID CONTENT OF WHITE BLOOD CELLS AND PLASMA TYROSINE LEVELS OF PREMATURE BABIES, FULL-TERM BABIES, AND TWO INFANTS WITH SCURVY

\begin{tabular}{|c|c|c|c|c|c|c|c|c|c|}
\hline \multicolumn{2}{|l|}{ Subjects } & $\begin{array}{l}\text { Case } \\
\text { Number }\end{array}$ & Sex & $\begin{array}{l}\text { Age } \\
\text { (days) }\end{array}$ & $\begin{array}{l}\text { Birth } \\
\text { Weight } \\
\text { (kg-) }\end{array}$ & $\begin{array}{l}\text { Gestation } \\
\text { Period } \\
\text { (weeks) }\end{array}$ & $\begin{array}{c}\text { Plasma } \\
\text { Tyrosine } \\
\text { (mg } / 100 \mathrm{ml} .)\end{array}$ & $\begin{array}{c}\text { Ascorbic Acid } \\
\text { in White } \\
\text { Blood Cells } \\
\left(\mu g .10^{6} \text { wbc) }\right.\end{array}$ & $\begin{array}{c}\text { Ascorbic } \\
\text { Acid } \\
\text { Intake } \\
\text { (mg.day) }\end{array}$ \\
\hline \multirow{10}{*}{ Premature babies } & \multirow[b]{4}{*}{$\cdots$} & $1 *$ & $\mathbf{M}$ & $\begin{array}{r}3 \\
10 \\
17 \\
24 \\
31\end{array}$ & $1 \cdot 71$ & 32 & $\begin{array}{l}3 \cdot 8 \\
5 \cdot 9 \\
2 \cdot 8 \\
2 \cdot 1 \\
3 \cdot 1\end{array}$ & $\begin{array}{l}35 \cdot 3 \\
14 \cdot 8 \\
24 \cdot 2 \\
24 \cdot 6 \\
38 \cdot 8\end{array}$ & $\begin{array}{r}\mathbf{0} \\
\mathbf{0} \\
\mathbf{3 0} \\
\mathbf{3 0} \\
\mathbf{3 0}\end{array}$ \\
\hline & & $2 *$ & $\mathbf{M}$ & $\begin{array}{r}3 \\
10 \\
17 \\
24 \\
31\end{array}$ & $1 \cdot 63$ & 32 & $\begin{array}{c}6 \cdot 1 \\
30 \\
4 \cdot 4 \\
3 \cdot 1 \\
4 \cdot 8\end{array}$ & $\begin{array}{l}29 \cdot 3 \\
22 \cdot 7 \\
38 \cdot 4 \\
34 \cdot 2 \\
43 \cdot 8\end{array}$ & $\begin{array}{r}\mathbf{0} \\
0 \\
\mathbf{3 0} \\
\mathbf{3 0} \\
\mathbf{3 0}\end{array}$ \\
\hline & & 3 & $\mathbf{F}$ & $\begin{array}{r}3 \\
10 \\
17 \\
24\end{array}$ & $2 \cdot 05$ & 32 & $\begin{array}{l}4 \cdot 1 \\
5 \cdot 2 \\
7 \cdot 6 \\
-\end{array}$ & $\begin{array}{l}46 \cdot 9 \\
21 \cdot 1 \\
25 \cdot 5 \\
23 \cdot 8\end{array}$ & $\begin{array}{l}\mathbf{0} \\
\mathbf{0} \\
\mathbf{0} \\
\mathbf{0}\end{array}$ \\
\hline & & $4^{+}$ & $\mathbf{M}$ & $\begin{array}{r}3 \\
10 \\
17\end{array}$ & $2 \cdot 35$ & 35 & $\begin{array}{l}10 \\
26 \\
3 \cdot 5\end{array}$ & $\begin{array}{l}43 \cdot 7 \\
32 \cdot 1 \\
24 \cdot 6\end{array}$ & $\begin{array}{r}0 \\
30 \\
60\end{array}$ \\
\hline & & $5^{+}$ & $\mathbf{M}$ & $\begin{array}{r}3 \\
10 \\
17\end{array}$ & $2 \cdot 20$ & 35 & $\begin{array}{l}7 \cdot 5 \\
28 \\
13\end{array}$ & $\begin{array}{l}51 \cdot 5 \\
33 \cdot 6 \\
31 \cdot 1\end{array}$ & $\begin{array}{r}0 \\
30 \\
60\end{array}$ \\
\hline & $\vdots$ & 6 & $\mathbf{F}$ & $\begin{array}{r}9 \\
16\end{array}$ & $2 \cdot 33$ & 36 & $\begin{array}{l}2 \cdot 6 \\
3 \cdot 4\end{array}$ & $\begin{array}{l}23 \cdot 2 \\
29 \cdot 8\end{array}$ & $\begin{array}{l}22 \\
30\end{array}$ \\
\hline & 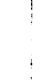 & $7 \dagger$ & $\mathbf{F}$ & $\begin{array}{r}1 \\
8 \\
15\end{array}$ & $1 \cdot 78$ & 38 & $\begin{array}{l}1 \cdot 6 \\
5 \cdot 2 \\
5 \cdot 2\end{array}$ & $\begin{array}{l}19 \cdot 9 \\
21 \cdot 3 \\
33 \cdot 6\end{array}$ & $\begin{array}{r}\mathbf{0} \\
\mathbf{0} \\
\mathbf{3 0}\end{array}$ \\
\hline & $!$ & $8^{+}$ & $\mathbf{F}$ & 1 & $2 \cdot 21$ & 38 & $2 \cdot 5$ & $15 \cdot 6$ & 0 \\
\hline & & 9 & $\mathbf{F}$ & $\begin{array}{l}10 \\
17\end{array}$ & $2 \cdot 14$ & 40 & $\begin{array}{l}2 \cdot 8 \\
5 \cdot 2\end{array}$ & $\begin{array}{l}15 \cdot 4 \\
18 \cdot 5\end{array}$ & $\begin{array}{l}30+ \\
30 \div\end{array}$ \\
\hline & & 10 & $\mathbf{M}$ & 8 & $2 \cdot 33$ & 40 & 21 & $28 \cdot 7$ & $\mathbf{0}$ \\
\hline & & 31 cases & $\left.\begin{array}{l}21 \mathrm{M} \\
10 \mathrm{~F}\end{array}\right\}$ & $0-6$ & & Full-term & $\begin{array}{c}1.97^{+} \\
(0.93)_{\S}\end{array}$ & $\begin{array}{c}23 \cdot 88 \\
(7 \cdot 57)\end{array}$ & 一 \\
\hline Full-term babies & $\cdots$ & 8 caser & $\left.\begin{array}{l}3 M \\
5 F\end{array}\right\}$ & $7-10$ & & Full-term & $\begin{array}{l}2 \cdot 24 \\
(0 \cdot 44)\end{array}$ & $\begin{array}{l}23 \cdot 84 \\
(5 \cdot 02)\end{array}$ & 一 \\
\hline Infantile scurvy & & a) & $\mathbf{M}$ & 9 mth. & $3 \cdot 18$ & Full-term & $4 \cdot 7$ & $3 \cdot 0$ & $?$ \\
\hline Heariue seury & $\cdots$ & b) & $\mathbf{M}$ & $10 \mathrm{mth}$. & $?$ & Full-term & $1 \cdot 4$ & $1 \cdot 5$ & $?$ \\
\hline
\end{tabular}

- Probable monozygotic twins; + dizygotic twins; $\ddagger 23$ subjects; $\$$ Figures in parentheses are standard deviations.

tyrosine level of $41 \mathrm{mg} . / 100 \mathrm{ml}$. The highest plasma tyrosine level observed (57 mg./100 ml.) was in a baby who had started a daily dose of $30 \mathrm{mg}$. of ascorbic acid 3 days previously; 12 days later the plasma tyrosine level was still high $(37 \mathrm{mg} . / 100 \mathrm{ml}$.).

Tissue Ascorbic Acid Levels. In view of the previous findings it seemed important to measure the tissue ascorbic acid levels. These are shown in Table 4. The baby's age, birth weight, estimated gestation period, plasma tyrosine level, and ascorbic acid intake are shown as well as the plasma tyrosine level and ascorbic acid content of the white blood cells in a number of full-term babies and two cases of infantile scurvy.

Several points are illustrated by this Table. In the first place, the wide variation of plasma tyrosine levels amongst the premature babies in the first and, more particularly, the second weeks of life were in marked contrast to the small variations found in the plasma tyrosine levels of the full-term babies. The ascorbic acid content of the white blood cells of the premature babies in the first week of life was the same as (Cases 1, 2, 7, 8) or significantly higher than (Cases 3, 4, 5) that found in full-term babies of the same age. In the second week of life the ascorbic acid content of the white cells was within the same range in premature and full-term babies. In the older premature babies the ascorbic acid content of the white cells increased (Cases 1, 2, 7), or remained the same (Case 5), following the introduction of ascorbic acid to the diet except for one baby (Case 4), in whom a decrease was seen. There was no suggestion of any tissue ascorbic acid deficiency in the 
premature babies at any age comparable to that found in the two cases of scurvy. There was no relation between the ascorbic acid content of the white blood cells and the plasma tyrosine levels in general or in any individual baby.

\section{Case Reports}

Three cases will be briefly presented to illustrate these findings.

Case 11. She was delivered at 33 weeks' gestation by caesarean section because of premature rupture of the membranes and prolapse of the umbilical cord. The clinical condition at birth was fair (Apgar rating at one minute $=7$ ). The birth weight was $1 \cdot 72 \mathrm{~kg}$. The baby was fed glucose water by nasogastric tube for two days followed by 'Olac' in increasing strengths and quantities. Clinical progress was satisfactor $y$.

Fig. 4 shows the protein and ascorbic acid intake, the weight, Millon's reaction of the urine, and the plasma tyrosine levels during the first 45 days of life. For the first two weeks the protein intake increased to a little over $5.0 \mathrm{~g} . \mathrm{kg}$. $/$ day. The urine was negative to Millon's reaction; the plasma tyrosine was $7.4 \mathrm{mg}$. on the seventh day and $4.2 \mathrm{mg}$. $100 \mathrm{ml}$. on the eighteenth day. Ascorbic acid (30 mg. day) was started on the fourteenth day. At the age of 3 weeks the protein intake increased to about 8.0 g. $\mathrm{kg}$. day. On the twenty-eighth day the plasma tyrosine rose to $35 \mathrm{mg}$. $100 \mathrm{ml}$. and Millon's test on the urine was positive. Despite an increase of protein intake the plasma tyrosine fell to $18 \mathrm{mg}$. $100 \mathrm{ml}$. on the thirty-fifth day of life and to $3.8 \mathrm{mg}$. $100 \mathrm{ml}$. on the forty-second day; Millon`s test remained positive.

Cases 1 and 2. Twin boys were born at 32 weeks' gestation. The first baby, Case 1 (Twin A), was a breech delivery: one minute Apgar rating was 7: the birth weight was $1.71 \mathrm{~kg}$. The second baby, Case 2 (Twin B), was also a breech delivery; one minute Apgar rating was 3; the birth weight was $1.63 \mathrm{~kg}$. There was a single placenta. Both babies had mild respiratory distress for 24 hours after birth but thereafter clinical progress was good. Both babies were fed glucose water for $\mathbf{2 4}$ hours followed by 'Olac'.

The twins' progress in hospital is shown in Fig. 5, and the plasma tyrosine levels and tissue ascorbic acid estimations are shown in Table 4 (Cases 1 and 2). For the first two weeks of life the protein intake and weight change of the two babies were almost identical. In contrast there was a marked difference in the plasma tyrosine levels. On the third and tenth days of life, Twin $A$ had levels of 3.8 and $5.9 \mathrm{mg}$. of tyrosine $/ 100 \mathrm{ml}$. compared with $6 \cdot 1$ and $30 \mathrm{mg}$. of tyrosine $/ 100 \mathrm{ml}$. in Twin B. Haemoglobin estimations on the sixth day were $18.6 \mathrm{~g} .100 \mathrm{ml}$. in Twin A and $19.6 \mathrm{~g}$. $100 \mathrm{ml}$. in Twin B.

Following the administration of ascorbic acid $(30 \mathrm{mg}$. day) on the thirteenth day of life, the plasma tyrosine level fell to under $5 \mathrm{mg}$. $100 \mathrm{ml}$. in both babies but that in Twin B was slightly higher than that in Twin A on the three subsequent occasions that the level was measured.

In the neonatal period, and again at the age of 5 months, the twins were compared with regard to facial appearance, hair colour, iris colour, hair whorl, external ear configuration, and fingerprints. All these traits were closely similar or identical. The blood groups $\left(A_{1}, M N\right.$, $\mathrm{P}_{2}, \mathrm{CDe} / \mathrm{cde}, \mathrm{K}-\mathrm{k}-, \mathrm{Kp}(\mathrm{b})-$, Le(a-b-), Fy(a)-, $\mathrm{Vel}-, \operatorname{Wr}(\mathrm{a})-, \mathrm{Vw}-, \mathrm{Jk}(\mathrm{b})-$ ) were the same in both babies. Both babies had similar types $\left(\mathrm{Hp}^{2}\right)$ of serum haptoglobin (Connell, Dixon, and Smithies, 1962).

From the blood groups alone the probability of the twins being dizygotic was estimated to be about only 1 in 20 (B. P. L. Moore, 1963, personal communication). It was concluded from this, and the striking similarity in the two babies of the other traits studied, that the twins were monozygotic.

Over the whole series, no relation was found between the development of a high plasma tyrosine level (over $10 \mathrm{mg} . / 100 \mathrm{ml}$.) and the baby's sex, maternal age or parity or the presence of fever: no cases of clinically significant jaundice were seen.

\section{Discussion}

In their investigations into the tyrosine metabolism of premature babies, Levine and his colleagues made most of their observations on the urine: in other words they studied tyrosyluria. Most of the present observations were made on plasma tyrosine levels. It is clear from Fig. 1 that, although there is a certain degree of correlation between a raised plasma tyrosine level and tyrosyluria (as judged by Millon's reaction), the two phenomena are not directly related. This may account for some of the discrepancies between the findings of Levine and our own.

Like Levine (1947) we have found that, in general, those premature babies who took less than about $5.0 \mathrm{~g}$. of protein $/ \mathrm{kg}$./day maintained an apparently normal tyrosine metabolism, i.e. similar to that usually found in full-term babies and older subjects. With greater amounts of dietary protein about onethird of the babies developed very high plasma tyrosine levels (over $20 \mathrm{mg}$./100 ml.); the remaining babies had an average plasma tyrosine level somewhat higher than normal but the level was usually less than $10 \mathrm{mg} . / 100 \mathrm{ml}$. A possible reason for this bimodal distribution of values is that the baby may have two series of metabolic readjustments which it can make in the face of a high tyrosine intake. The first readjustment (perhaps, an increased excretion of tyrosine in the urine) allows the plasma tyrosine level to remain below $10 \mathrm{mg} . / 100 \mathrm{ml}$. If this mechanism becomes exhausted then a second readjustment (perhaps the use of alternative metabolic pathways) may come into play that allows the concentration of tyrosine in the blood to rise to over $20 \mathrm{mg}$. $/ 100 \mathrm{ml}$. There is some evidence that the level of phenylalanine in the blood in phenylketonuria is controlled by 
this sort of dual mechanism (M. W. Partington, 1961, unpublished data).

Two explanations may be offered as to why some of the premature babies on high protein intakes developed high plasma tyrosine levels and some did not. In the first place there could be a genetic difference between the two groups. This helps to explain the lack of any direct relation between the plasma tyrosine level and birth weight or maturity, but is completely contradicted by the observations on the twins (Cases 1 and 2), if these were, as seems highly probable, monozygotic. A second explanation is that there is a delayed maturation of the tyrosine enzyme systems due to the deficiency of a co-factor. Menkes and Avery (1963) have suggested this in relation to the phenylalanine hydroxylase system to account for their results with phenylalanine load tests in premature babies. They found that a baby with a normal phenylalanine load test in the first 48 hours of life might have an abnormal load test a week later. This could be explained by postulating a maternally transmitted phenylalanine hydroxylase cofactor, whose synthesis is delayed in the premature infant ${ }^{\circ}$ or which is deficient in the diet. The same hypothesis in relation to tyrosine metabolism is compatible with the present observations, since it is conceivable that, through minor inequalities of blood supply in utero, one of a pair of monozygotic twins could receive less of a humoral agent from the mother. Furthermore, the amount of humoral agent the baby received from the mother need not depend directly on the gestation period or birth weight.

In view of Levine's observations, the natural candidate for this hypothetical co-factor would be ascorbic acid. However, we have been unable to show that the premature has less tissue ascorbic acid than the full-term baby: indeed the premature baby may be more generously supplied (Table 4 ). There was no question of those babies who developed high plasma tyrosine levels having a tissue deficiency of ascorbic acid comparable to that found in scurvy. Furthermore, there was no obvious relation between the ascorbic acid content of the white blood cells and the plasma tyrosine level. This evidence suggests that the development of a raised plasma tyrosine level in premature babies does not depend on any physiological deficiency of ascorbic acid.

This agrees with the conclusions of $\mathrm{La} \mathrm{Du}$ and Zannoni (1961) that, although ascorbic acid is involved in the breakdown of tyrosine when large amounts of tyrosine are being metabolized, the action of ascorbic acid is non-specific and unrelated to its antiscorbutic properties.

High protein milk formulae are commonly used for feeding premature babies. It seems clear that approximately one-third of premature babies on this regime will experience a considerable increase in the blood tyrosine level in the neonatal period. Furthermore, it does not seem possible to prevent this by giving supplemental ascorbic acid in customary dosage. The need to establish whether such rises in the blood tyrosine level are harmful or not is obvious.

\section{Summary}

The plasma tyrosine level was studied in 40 premature babies in relation to birth weight, gestation period, the protein and ascorbic acid intake, Millon's reaction of the urine, and the ascorbic acid content of the white blood cells. Approximately $35^{\circ}{ }_{0}$ of those babies who received more than $5 \cdot 0 \mathrm{~g}$. of protein $/ \mathrm{kg}$./day had plasma tyrosine levels above $20 \mathrm{mg} . / 100 \mathrm{ml}$. The development of these high plasma tyrosine levels was not consistently related to birth weight, maturity, ascorbic acid intake, or the ascorbic acid content of the white blood cells. One of a pair of monozygotic twins, on similar protein intakes, developed high plasma tyrosine levels and the other did not.

The importance of finding out whether increases in the blood tyrosine level in the neonatal period are harmful or not is emphasized.

We are indebted to Dr. Don Delahaye, physician to the Premature Nursery, and the physicians at Kingston General Hospital for permission to investigate their patients; to the nurses of the Premature Nursery for their meticulous observations; and to Miss Barbara Sinnott for technical help. We would also like to thank Dr. B. P. L. Moore of the Canadian Red Cross Blood Transfusion Service for the determination of the blood groups, and Dr. George Connell. Department of Biochemistry, the University of Toronto, for the identification of the types of haptoglobin in Cases 1 and 2.

This investigation was aided by funds provided by the Child and Maternal Health Grants (No. 605-13-62) of the National Health Grants Programme and the Queen Elizabeth II Canadian Research Fund.

\section{REFERENCES}

Berman. P. W.. Graham. F. K.. Eichman. P. L. and Waisman. H. A (1961). Psvchologic and neurologic status of diet-treated phenylketonuric children and their siblings. Pediatrics. $28,924$.

Bloxam. H. R.. Day, M. G.. Gibbs. N. K. and Woolf, L. I. (1960). An inborn defect in the metabolism of tyrosine in infants on a normal diet. Biochem. J.. 77. 320.

Connell. G. E.. Dixon. G. H. and Smithies, O. (1962). Subdivision of the three common haptoglobin types based on "hidden" differences. Nature (Lond.), 193. 505.

Denson, K. W. and Bowers. E. F. (1961). The determination of ascorbic acid in white blood cells. Clin. Sci., 21, 157.

Etzwiler, D. D.. McNamara. H.. Kretchmer, N. and Levine, S. Z. (1957). The effect of corticotrophin on the renal clearance of tyrosine and para-hydroxyphenylpyruvate in premature infants. A.M.A. J. Dis. Child.. 94. 541.

Hsia. D. Y.. Litwack. M.. O'Flynn. M. and Jakovcic. S. (1962) Serum phenylalanine and tyrosine levels in the newborn infant. New Engl. J. Med., 267, 1067. 
Kitagawa. T. and Yoshioka. K. (1960). Millon's reaction positive substances in urine. Tokyo New Medicine. 47, 431.

Kretchmer. N. (1958). Metabolic and enzymic changes during development. In Physiology of Prematurity: Trans. Third Conference, ed. J. T. Lanman, p. 11. Josiah Macy Jr. Foundation, New York.

- and Etzwiler, D. D. (1958). Disorders associated with the metabolism of phenylalanine and tyrosine. Pediatrics, 21, 445.

La Du. B. N., Howell. R. R.. Michael, P. J. and Sober, E. K. (1963). A quantitative mictomethod for the determination of phenylalanine and tyrosine in blood and its application in the diagnosis of phenylketonuria in infants. ibid., 31, 39.

- and Zannoni. V. G. (1961). The role of ascorbic acid in tyrosine metabolism. Ann. N.Y. Acad. Sci.. 92, 175.

Levine. S. Z. (1947). Tyrosine and phenylalanine metabolism in infants and the role of vitamin C. Harvey Lectures 1946-47. Ser. 42, p. 303.

- (1956). Aromatic amino acid metabolism in premature infants. In Infant Metabolism: Proc. World Hith Org. Seminars. Leyden and Stockholm, 1950, ed. I. H. Scheinberg, p. 331. Macmillan, New York.

- Gordon. H. H. and Marples, E. (1941a). A defect in the metabolism of tyrosine and phenylalanine in premature infants.
2. Spontaneous occurrence and eradication by vitamin C. J. clin. Invest., 20. 209.

- Marples. E. and Gordon. H. H. (1941b). A defect in the metabolism of tyrosine and phenylalanine in premature infants 1. Identification and assay of intermediary products. ibid.. 20. 199.

Menkes J. H. and Avery. M. E. (1963). Phenylalanine and tyrosine metabolism in the premature infant. Abstracts of the 33rd annual meeting of Society for Pediatric Research. May.

_ and Jervis, G. A. (1961). Developmental retardation associated with an abnormality in tyrosine metabolism. Pediatrics, 28, 399.

Morris J. E., Harpur, E. R. and Goldbloom, A. (1950). The metabolism of L-tyrosine in infantile scurvy. J. clin. Invest., 29, 325.

Nitowsky, H. M., Govan, C. D. and Gordon, H. H. (1953). Effect of hemopoietic and other agents on the hydroxyphenyluria of premature infants . A.M.A. Amer. J. Dis. Child., 85, 462.

Partington, M. W. and Lewis. E. J. M. (1963). Variations with age in the plasma phenylalanine and tyrosine levels in phenylketonuria. J. Pediat., 62, 348.

Sealock. R. R. and Silberstein, S. E. (1940). The excretion of homogentisic acid and other tyrosine metabolites by the vitamin C-deficient guinea pig. J. biol. Chem.. 135, 251.

Udenfriend, S. and Cooper, J. R. (1952). The chemical estimation of tyrosine and tyramine. ibid., 196, 227. 